\title{
NATURAL HISTORY OF THE WORKERLESS INQUILINE ANT POGONOMYRMEX COLEI (HYMENOPTERA: FORMICIDAE)*
}

\author{
By Steven W. Rissing \\ Department of Zoology \\ Arizona State University \\ Tempe, Arizona 85287
}

\begin{abstract}
At least 10 workerless inquiline ant species are known from North America (Francoeur 1968, 1981; Wilson 1971, 1976; Talbot 1976; Buschinger 1979; DuBois 1981; Snelling 1981), most only from original collections. In this paper I present field and laboratory observations of Pogonomyrmex colei Snelling a new, apparently workerless, inquiline ant inhabiting a colony of Pogonomyrmex rugosus.
\end{abstract}

P. colei appears to be a very rare species: extensive searching of the type locality for $4 \mathrm{yr}$ has resulted in discovery of only a single colony. Nonetheless, observations on this colony provide insight into several important aspects of inquiline ant biology. P. colei is also of interest since it is the second apparently workerless congeneric inquiline inhabiting colonies of $P$. rugosus. Cole discovered the first inquiline species, Pogonomyrmex anergismus, near Silver City, New Mexico apparently prior to any major flight since he exposed "more than one hundred" inquiline reproductives upon opening the host nest (Cole 1954, 1968). Since host species mating flights occur soon after rain during mid to late summer (Hölldobler 1976; Rissing personal observation), it seemed reasonable to suspect $P$. anergismus responds to the same environmental cues for mating as does its host. Accordingly, in an effort to rediscover P. anergis$m u s$, I routinely checked most $P$. rugosus nests on a 25 ha study area in Boulder City, Nevada for flight activities and possible presence of inquilines during late summer 1978 and 1979 (study area described in Rissing 1981). P. colei was discovered during this effort.

*Manuscript received by the editor June 7, 1983 


\section{OBSERVATIONS}

Mating Activities and Season. Five $P$. colei males were collected at a single $P$. rugosus nest during the morning of 13 August 1978; a series of thunderstorms and rain had occurred $12 \mathrm{hr}$ earlier. Frenzied host worker activity suggested a mating flight or similar activity occurred immediately prior to my arrival. No flights of either species occurred at any nearby $P$. rugosus nests observed simultaneously.

I observed a complete inquiline and host flight at this same nest on 15 September 1978 following an extensive rain storm the preceding day. Flights were occurring at 2 of 23 nearby $P$. rugosus nests; $P$. colei was not found at any other nest. Mating activities began with accumulation of several hundred host workers in and around the nest crater. These workers pugnaciously defended the area throughout both flights as is typical during $P$. rugosus flights (Rissing, personal observation). As ground and air temperatures increased male $P$. colei climbed to the crater and were soon joined by much larger females. While both sexes of $P$. colei are winged, mating occurred at the nest entrance followed by females flying from the area and males re-entering the nest. Such in situ mating is common in rare ant species apparently due to very low probability of reproductives finding individuals from other nests with which to mate (Wilson 1963). Following copulation and departure of $P$. colei females, male and female $P$. rugosus flew from the crater as the temperature continued to climb. Reproductive forms of $P$. rugosus fly to a site away from the nest and copulate there (Hölldobler 1976). Mating activities of host and inquiline were separated by at least $30 \mathrm{~min}$ and, perhaps more importantly, $3^{\circ} \mathrm{C}$ ground temperature (Table 1). Reproductive forms of each species were seen occasionally in the nest entrance during the mating activity of the other. On at least one occasion, $P$. colei males tried unsuccessfully to mount a $P$. rugosus female. During this flight I observed no differences in behavior of host workers to host or inquiline reproductives. $P$. rugosus workers frequently encircled copulating pairs of $P$. colei and frantically ran around them, although they never interfered.

During 1979 routine observations were begun at the study area on 18 September. A complete $P$. colei flight was observed at the host nest during the afternoon of $\mathbf{3 0}$ September immediately following a 
trace of rain. No flights of either species were observed at 35 nearby $P$. rugosus nests during this time. On 8 October 1979 I poured approximately 7.51 of water directly onto the host nest crater resulting in an immediate flight of $P$. colei. This procedure was repeated unsuccessfully on 17 and 18 September 1982. Viability of the host nest (as determined by worker activity, size of crater and refuse pile, and absence of plants growing in the crater) has remained constant and similar to that of nearby $P$. rugosus colonies from 1978 to 1982 . I have never observed any forms that might be considered $P$. colei workers.

Colony foundation. Ten newly mated $P$. colei females from the 15 September 1978 flight were placed into a $7.5 \mathrm{~m}$ high flight enclosure made of plastic sheeting and permitted to fly. Subsequent to this all females removed their wings but did not dig burrows when placed into laboratory nest boxes containing moist sand. Five of these dealate inquilines were transferred to 5 laboratory nests containing only newly mated $P$. rugosus queens. These $P$. rugosus queens had been collected one week earlier at a mating site $3.2 \mathrm{~km}$ from the host nest making it unlikely that they were related to the host colony. Four of these laboratory nests contained a single, mated dealate $P$. rogusus queen; the fifth contained two $P$. rugosus queens. The $P$. colei queen added to the nest with two $P$. rugosus queens was immediately attacked and removed from the glass tube occupied by the $P$. rugosus queens. Of the $P$. colei queens added to the single queen $P$. rugosus colonies, one was found dead within several hours (decapitated), and the other was found dead (entire) $5 \mathrm{~d}$ later. The other two $P$. colei queens lived peacefully along side the $P$. rugosus queens for at least a month. During this time I frequently observed the $P$. cole $i$ queens grooming the $P$. rugosus queens; $P$. rugosus queens did not reciprocate. These last two colonies ultimately failed during (or possibly in response to) transportation from Boulder City to Seattle.

Five other newly mated, dealate $P$. colei queens were released in the field at the entrance of large, active $P$. rugosus colonies near the host nest. Inquilines were always removed immediately from the nest by one or more workers and dropped several meters from the crater. The $P$. colei queens made no attempt to re-enter these nests following removal. 


\section{Discussion}

Repeated (and continuing) attempts to find $P$. colei or $P$. anergismus around Boulder City, NV, or Globe, AZ, where a single $P$. colei male has been collected (Snelling 1981) have yet to be successful. Nonetheless, observations of $P$. cole $i$ from the type nest in Boulder City provide insight into several questions of general inquiline biology including possible method of inquiline entry into host colonies and fate of host queen.

Inquiline entry into host colonies. Newly mated $P$. colei queens are accepted into 1 week old workerless host nests in the laboratory, while they appear incapable of entering established host nests in the field (see above). Similar observations have been made in laboratory experiments with the inquiline Plagiolepis xene and its host, Plagiolepis pygmaea (Passera 1964). This suggests that at least some inquiline species enter a host colony at the founding stage prior to production of any workers. That this may occur in the field is supported by discovery of a workerless inquiline queen (Strumigenys xenos) in an incipient host colony containing one queen, brood and a single worker of Strumigenys perplexa (Brown 1955).

If entry into host colony commonly occurs at host colony foundation in some species of inquilines, overlap with host species flight season would be advantageous. Since all nests of a given species in a locality tend to have a longer "flight season" than any single nest (e.g. for P. rugosus see Hölldobler 1976), the inquiline might further be expected to lengthen its flight season relative to that of its host colony to take advantage of the entire flight season and availability of founding nests in its locality. The extended flight season of $P$. colei relative to that of $P$. rugosus may occur for these reasons. Similarly, occurrence of $P$. anergismus reproductives during mid September in the type nest reported by Cole $(1954,1968)$ may also indicate inquiline-host reproductive overlap.

Fate of host queens. Simultaneous production of host and inquiline reproductives during the 1978 flight (Table 1) strongly suggests coexistence of host and inquiline queen(s) at that time. Continuing existence of the host colony until at least September 1982 further substantiates this. Estimates of maximum longevity of worker ants is 1-2 yr (Rosengren 1971, Brian 1972, Nielsen 1972). Further, there has never been a reported case of queen adoption in any Pogonomyrmex species. For the host colony to have a normal foraging 
Table 1. Summary of mating activities of $P$. colei and P. rugosus in Boulder City, Nevada, 15 September 1978.

\begin{tabular}{|c|c|c|c|}
\hline Time & $\begin{array}{l}\text { Ground } \\
\text { Temp. }{ }^{\circ} \mathrm{C}^{\prime}\end{array}$ & $\begin{array}{c}\text { Air } \\
\text { Temp. }{ }^{\circ} \mathrm{C}^{2}\end{array}$ & Activity \\
\hline 08:55 & & & $\begin{array}{l}\text { Reproductives of both species in nest } \\
\text { entrance }\end{array}$ \\
\hline 09:10 & 20.5 & 20.5 & $P$. colei reproductives on crater \\
\hline 09:37 & 21.0 & 21.5 & Number of $P$. colei increases \\
\hline 10:03 & & & First $P$. colei copulation \\
\hline $10: 45$ & 26.0 & 23.8 & First $P$. colei female flies \\
\hline 12:15 & 29.2 & 25.5 & Last $P$. colei female flies \\
\hline $12: 47$ & 32.6 & 26.4 & First $P$. rugosus male and female fly \\
\hline 13:15 & 33.4 & 30.8 & Last $P$. rugosus flies \\
\hline
\end{tabular}

'Temperature as determined by holding tip of a Yellow Springs Instruments direct read thermistor (YSI \#405) on ground surface; temperature read on a Yellow Springs Instruments telethermometer (YSI \#43TA).

${ }^{2}$ Temperature determined as above with thermistor $30 \mathrm{~cm}$ above ground and shaded.

group size in 1982, the host queen must have been alive during the 1978 and 1979 inquiline flights. Although inquiline-host coexistence has been regarded as a "primitive" inquiline trait (Wheeler 1933, Haskins and Haskins 1964), it offers the obviously adaptive advantage of a continuously renewed host worker force for the inquiline. Coexistence occurred in the type nest of $P$. colei and appears common in other workerless inquiline species where information regarding fate of host queen(s) is available (Table 2).

Host queen elimination does occur in at least two well documented cases (Table 2). Wilson (1971) suggests such behavior may develop in short-lived inquiline species; inquiline longevity, however, may be more of an effect than a cause of this behavior. Host queen elimination may be adaptive only when inquiline entry is gained by a queen after development of a host worker force. Host workers appear to be the primary defense against inquiline entry in many colonies. In order to be accepted by host workers, it may be necessary for the prospective inquiline queen to first render the prospective host colony queenless. In those cases where host queens are known or highly suspected of being eliminated (Table 2), the inquiline queen enters an established colony containing workers. In at least one of these cases, Epimyrma vandeli, the inquiline must fight with host workers until she is able to kill the host queen. Recent discovery that $E$. vandeli is a degenerate slave-maker 
Table 2. Fate of host queen(s) for workerless inquilines. Only those species whose host queen(s) fate is known are listed.

\begin{tabular}{|c|c|c|c|}
\hline Inquiline species & Host species & $\begin{array}{l}\text { Fate of host } \\
\text { queen(s) }\end{array}$ & Reference \\
\hline \multicolumn{4}{|c|}{ MYRMECIINAE } \\
\hline $\begin{array}{l}\text { Myrmecia } \\
\text { inquilina }\end{array}$ & $\begin{array}{l}\text { Myrmecia } \\
\text { vindex }\end{array}$ & survives & $\begin{array}{l}\text { Douglas and Brown } 1959 \\
\text { Haskins and Haskins } 1964\end{array}$ \\
\hline \multicolumn{4}{|c|}{ MYRMICINAE } \\
\hline $\begin{array}{l}\text { Myrmica } \\
\text { hirsuta }\end{array}$ & $\begin{array}{l}\text { Myrmica } \\
\text { sabuleti }\end{array}$ & survives & Elmes $1974 a, 1978$ \\
\hline $\begin{array}{l}\text { Sifolinia } \\
\text { laurae }\end{array}$ & $\begin{array}{l}\text { Myrmica } \\
\text { sabuleti }\end{array}$ & survive & Brian 1972 \\
\hline $\begin{array}{l}\text { Pogonomyrmex } \\
\text { colei }\end{array}$ & $\begin{array}{l}\text { Pogonomyrmex } \\
\text { rugosus }\end{array}$ & survive* & this study \\
\hline $\begin{array}{l}\text { Anergates } \\
\text { atratulus }\end{array}$ & $\begin{array}{l}\text { Tetramorium } \\
\text { caespitum }\end{array}$ & $\begin{array}{l}\text { apparently } \\
\text { killed by host } \\
\text { workers }\end{array}$ & $\begin{array}{l}\text { Wheeler } 1910 \text {, Crawley } 1912 \text {, } \\
\text { Donisthorpe } 1915 \text {, Creighton } \\
1950\end{array}$ \\
\hline $\begin{array}{l}\text { Teleutomyrmex } \\
\text { schneideri }\end{array}$ & $\begin{array}{l}\text { Tetramorium } \\
\text { caespitum }\end{array}$ & survives & $\begin{array}{l}\text { Stumper } 1950+\text {, } \\
\text { Kutter } 1969\end{array}$ \\
\hline $\begin{array}{l}\text { Leptothorax } \\
\text { kutteri }\end{array}$ & $\begin{array}{l}\text { Leptothorax } \\
\text { acervorum }\end{array}$ & survive & Buschinger 1965 \\
\hline $\begin{array}{l}\text { Leptothorax } \\
\text { minutissimus }\end{array}$ & $\begin{array}{l}\text { Leptothorax } \\
\text { curvispinosus }\end{array}$ & survive & $\begin{array}{l}\text { Smith 1942, } \\
\text { Buschinger } 1981\end{array}$ \\
\hline $\begin{array}{l}\text { Epimyrma } \\
\text { vandeli }\end{array}$ & $\begin{array}{l}\text { Leptothorax } \\
\text { nigriceps }\end{array}$ & $\begin{array}{l}\text { killed by } \\
\text { inquiline }\end{array}$ & $\begin{array}{l}\text { Vandel } 1927 \\
\text { Stumper and Kutter } 1951\end{array}$ \\
\hline $\begin{array}{l}\text { Doronomyrmex } \\
\text { pacis }\end{array}$ & $\begin{array}{l}\text { Leptothorax } \\
\text { acervorum }\end{array}$ & survive & Kutter $1945+, 1969+$ \\
\hline $\begin{array}{l}\text { Monomorium } \\
\text { pergandei }\end{array}$ & $\begin{array}{l}\text { Monomorium } \\
\text { minimum }\end{array}$ & survive* & Creighton 1950 \\
\hline $\begin{array}{l}\text { Doronomyrmex } \\
\text { pocahontas }\end{array}$ & $\begin{array}{l}\text { Leptothorax } \\
\text { muscorum }\end{array}$ & survive* & Buschinger 1979 \\
\hline $\begin{array}{l}\text { Monomorium } \\
\text { adulatrix }\end{array}$ & $\begin{array}{l}\text { Monomorium } \\
\text { salomonis }\end{array}$ & $\begin{array}{l}\text { killed by } \\
\text { host workers }\end{array}$ & $\begin{array}{l}\text { Wheeler } 1910 \\
\text { Forel } 1930\end{array}$ \\
\hline
\end{tabular}


Table 2. Continued.

\begin{tabular}{|c|c|c|c|}
\hline Inquiline species & Host species & $\begin{array}{l}\text { Fate of host } \\
\text { queen(s) }\end{array}$ & Reference \\
\hline $\begin{array}{l}\text { Monomorium } \\
\text { talbotae }\end{array}$ & $\begin{array}{l}\text { Monomorium } \\
\text { minimum }\end{array}$ & survives & Talbot 1979 \\
\hline $\begin{array}{l}\text { Strumigeny's } \\
\text { xenos }\end{array}$ & $\begin{array}{l}\text { Strumigeny's } \\
\text { perplexa }\end{array}$ & survive & Brown 1955, Taylor 1967 \\
\hline \multicolumn{4}{|c|}{ FORMICINAE } \\
\hline $\begin{array}{l}\text { Plagiolepsis } \\
\text { xene }\end{array}$ & $\begin{array}{l}\text { Plagiolepsis } \\
\text { pygmaea }\end{array}$ & survive & $\begin{array}{l}\text { Le Masne 1956; } \\
\text { Passera } 1964,1966,1972\end{array}$ \\
\hline $\begin{array}{l}\text { Aporomyrmex } \\
\text { ampeloni }\end{array}$ & $\begin{array}{l}\text { Plagiolepis } \\
\text { vindobonensis }\end{array}$ & survives & Faber 1969+ \\
\hline
\end{tabular}

(Buschinger 1981, Buschinger and Winter 1982) may explain this behavior which is rather unusual among most other inquilines (Table 2). Only the extreme inquiline Teleutomyrmex schneideri is known to enter established host nests without having to eliminate host queens; these inquilines may produce a substance highly attractive to host workers (reviewed in Wilson 1971).

Comparison with P. anergismus and other workerless inquilines. $P$. colei may represent an intermediate form between its host $P$. rugosus and the closely related workerless inquiline $P$. anergismus (for a complete discussion of morphological differences see Snelling 1981). Discovery of $P$. colei adds the genus Pogonomyrmex to a growing list of ant genera with more than one workerless inquiline species (Table 2). Such "concentration" of inquilines into a few genera may occur either due to non-random search by myrmecologists $(P$. colei was discovered during an intentional search for Pogonomyrmex inquilines) or because certain genera are more likely to give rise to inquilines. The basic biology of the inquilinerich genera, however, is quite variable suggesting several evolutionary routes may lead to workerless inquilinism. The genus Leptothorax, for example, has small, ephemeral colonies subject to slave raids from numerous species and has given rise to several closely 
related Epimyrma inquiline species, themselves degenerate slavemakers (Buschinger 1981, Buschinger and Winter 1982). Myrmica, on the other hand, has larger colonies and many species that are highly polygynous (Brian 1972; Elmes 1974a,b); this genus has given rise to at least 7 workerless inquiline species: Myrmica faniensis (van Boven 1970), Myrmica hirsuta (Elmes 1974a, 1978), Myrmica lampra (Francoeur 1968, 1981), Myrmica myrmecophila (Bernard 1968), Myrmica quebecensis (Francoeur 1981), Sifolinia karavajevi (Kutter 1969) and Sifolinia laurae (Brian 1972), the Sifolinia species likely being congeneric with the other Myrmica species (Elmes 1978). Monomorium is similar with polygynous species (Dennis 1938, Cole 1940, Gregg 1945) and a number of congeneric inquilines (reviewed in Wilson 1971, see also Talbot 1979 and DuBois 1981). These inquiline species may have evolved through a process of some polygynous host queens acquiring the trait of laying only reproductive eggs (Buschinger 1970, Elmes 1978). To this list must be added the genus Pogonomyrmex whose basic biology is unlike any of the above three host genera. Colonies are substantially larger than Leptothorax, Myrmica or Monomorium (Lavigne 1969, Rogers et al. 1972, Whitford et al. 1976, MacKay 1981), strictly monogynous (Lavigne 1969, Hölldobler and Wilson 1977, MacKay 1981), with no slave-making or similar behavior in any species. Evolutionary processes giving rise to $P$. colei and $P$. anergismus are likely different from those that have given rise to the Leptothorax, Myrmica or Monomorium inquilines. Certainly, the idea of multiple evolutionary pathways leading to workerless inquilinism is not new (see Wheeler 1919, Buschinger 1970, Wilson 1971). Continued study and search for workerless inquilines can only serve to clarify this challenging evolutionary process.

\section{ACKNOWLEDGEMENTS}

J. Alcock, G. B. Pollock, R. R. Snelling, G. C. Wheeler, and J. Wheeler have constructively reviewed earlier drafts of this manuscript. Laboratory space in Boulder City, Nevada was kindly provided by the University of Nevada Desert Research Institute, Desert Biology Research Center and the U.S. Bureau of Mines, Boulder City office. Portions of this work have been supported by an NSF Graduate Fellowship, NSF grant DEB 78-02069 (T. W. Schoener, principal investigator), NSF grant DEB 82-07052, and an Arizona State University Faculty Grant-in-Aid. 
Bernard, F.

\section{Literature Cited}

1968. Les fourmis (Hymenoptera Formicidae) d'Europe occidentale et septentrionale. Faune de l'Europe et du Bassin Méditteranéen, No. 3. Masson et Cie, Paris, France.

Boven, J. K. A. van

1970. Myrmica faniensis, une nouvelle espece parasite. Bull. ann. soc. entomol. Belg. 106: 127-132.

BRIAN, M. V.

1972. Population turnover in wild colonies of the ant Myrmica. Ekol. Pol. 20: 43-53.

Brown, W. L.

1955. The first social parasite in the ant tribe Dacetini. Insectes Soc. 2: 181186.

BusChinger, A.

1965. Leptothorax (Mychothorax) kutteri $\mathrm{n}$. sp. eine sozialparasitische Ameise (Hymenoptera, Formicidae). Insectes Soc. 4: 327-334.

1970. Neue Vorstellungen zur Evolution des Sozialparasitismus und der Dulosis bei Ameisen (Hym., Formicidae). Biologisches Zentralblatt 88: 273-299.

1979. Doronomyrmex pocahontas $\mathrm{n}$. sp., a parasitic ant from Alberta, Canada (Hymenoptera, Formicidae). Insectes Soc. 26: 216-222.

1981. Biological and systematic relationships of social parasitic Leptothoracini from Europe and North America. Pages 211-222 in P. E. Howse and J.L. Clement, eds., Systematics Association Special Volume No. 19, Biosystematics of Social Insects. Academic Press, New York.

BUSCHINGER, A. AND U. WinTER.

1982. Evolutionary trends in the parasitic ant genus Epimyrma. in: M. D. Breed, C. D. Michener and H. E. Evans, eds., The biology of social insects, pp. 266-269. Westview Press, Boulder, Colorado.

Cole, A. C.

1940. A guide to the ants of the Great Smoky Mountains National Park, Tennessee. Am. Midl. Natur. 24: 1-88.

1954. Studies of New Mexico ants. VII. The genus Pogonomyrmex with synonymy and a description of a new species (Hymenoptera: Formicidae). J. Tenn. Acad. Sci. 29: 115-121.

1968. Pogonomyrmex harvester ants. University of Tennessee Press, Knoxville.

Crawley, W. C.

1912. Anergates atratulus Schnek., a British ant, and the acceptance of a $\$$ by Tetramorium caespitum, L. The Entomol. Rec. 24: 218-219.

Creighton, W. S.

1950. The ants of North America. Bull. Mus. Comp. Zool. Harvard 104: 1-585.

Dennis, C. A.

1938. The distribution of ant species in Tennessee with (special) reference to ecological factors. Ann. Entomol. Soc. Am. 31: 267-308.

\section{DONISTHORPE, $\mathrm{H}$.}

1915. British ants, their life-history and classification. Wm. Breden \& Son, Plymouth, England. 
Douglas, A. and W. L. Brown.

1959. Myrmecia inquilina new species: the first parasite among the lower ants. Insectes Soc. 6: 13-19.

DuBois, M. B.

1981. Two new species of inquilinous Monomorium from North America (Hymenoptera:Formicidae). Univ. Kansas Sci. Bull. 52: 31-37.

Elmes, G. W.

1974a. The effect of colony population size in three species of Myrmica (Hymenoptera, Formicidae). Insectes Soc. 21: 213-230.

1974b. Colony populations of Myrmica sulcinodis Nyl. (Hym., Formicidae). Oecologia (Berl.) 15: 337-343.

1978. A morphometric comparison of three closely related species of Myrmica (Formicidae), including a new species from England. Syst. Entomol. 3: 131-145.

FABER, W.

1969. Beitrage zur Kenntnis sozialparasitischer Ameisen. 2. Aporomyrmex ampeloni nov. gen., nov. spec. (Hym. Formicidae), ein neuer permanenter Sozialparasit bei Plagiolepis vindobonensis Lomnicki aus Osterreich. Pflanzenschutzberichte 39: 39-100.

FOREL, A.

1930. The social world of the ants compared with that of man. (Tr: C. K. Ogden). Albert \& Charles Boni, New York.

Francoeur, A.

1968. Une novelle espèce du genre Myrmica au Québec (Formicidae, Hymenoptera) Naturaliste Can. 95: 727-730.

1981. Le groupe Néarctique Myrmica lampra (Formicidae, Hymenoptera). Can. Ent. 113: 755-759.

GREGG, R. E.

1945. Two new forms of Monomorium (Formicidae). Psyche 52: 62-69.

Haskins, C. P. AND E. F. Haskins.

1964. Notes on the biology and social behavior of Myrmecia inquilina. The only known myrmeciine social parasite. Insectes Soc. 11: 267-282.

HöLLDOBLER, B.

1976. The behavioral ecology of mating in harvester ants (Hymenoptera: Formicidae: Pogonomyrmex). Behav. Ecol. Sociobiol. 1: 405-423.

HOLLDOBLER, B. AND E. O. WILSON.

1977. The number of queens: an important trait in ant evolution. Naturwissenschaften 64: 8-15.

KUTTER, H.

1945. Eine neue Ameisengattung. Mitt. Schweiz. Entomol. Ges. 23: 81-94.

1969. Die sozialparasitischen Ameisen der Schweiz. Neujahrsblatt herausgegeben von der Naturforschenden Gesellschaft in Zurich 171: 1-62.

LAVIGNE, R. J.

1969. Bionomics and nest structure of Pogonomyrmex occidentalis (Hymenoptera: Formicidae). Ann. Entomol. Soc. Am. 62: 1166-1175.

Le Masne, G.

1956. Recherches sur les fourmis parasites Plagiolepis grassei et l'evolution des Plagiolepis parasites. C. R. Acad. Sci. (Paris) 243: 673-675. 
MacKay, W. P.

1981. A comparison of the nest phenologies of three species of Pogonomyremex harvester ants (Hymenoptera; Formicidae). Psyche 88: 25-74.

Nielsen, M. G.

1972. Production of workers in an ant nest. Ekol. Polska 20: 65-71. Passera, L.

1964. Données biologiques sur la fourmi parasite Plagiolepis xene Starcke. Insectes Soc. 1: 59-70.

1966. Fécondité des femelles au sein de la myrmécobiose Plagiolepis pygmaea Latr.-Plagiolepis xene (Hyménoptères, Formicidae). C. R. Acad. Sci. (Paris) 263: 1600-1603.

1972. Longévité des fourmilières de Plagiolepis pygmaea Latr. infestées par le parasite social Plagiolepis xene St. (Hymenoptera, Formicidae). C. R. Acad. Sci. (Paris) 275: 409-411.

RISsing, S. W.

1981. Prey preferences in the desert horned lizard: influence of prey foraging methods and aggressive behavior. Ecology 62: 1031-1040.

Rogers L., R. Lavigne and J. L. Miller.

1972. Bioenergetics of the western harvester ant in the shortgrass plains ecosystem. Environ. Entomol. 1: 763-768.

ROSENGREN, R.

1971. Route fidelity, visual memory and recruitment behavior in foraging wood ants of the genus Formica (Hymenoptera, Formicidae). Acta Zool. Fennica 133: 1-106.

SMITh, M. R.

1942. A new apparently parasitic ant. Proc. Entomol. Soc. of Washington 44: 59.

SNelling, R. R.

1981. The taxonomy and distribution of some North American Pogonomyrmex and descriptions of two new species (Hymenoptera: Formicidae). Bull. Southern California Acad. Sci. 80: 97-112.

STUMPER, R.

1950. Les associations complexes des fourmis. Commensalisme, symbiose et parasitisme. Bull. Biol. Fr. Belg. 84: 376-399.

Stumper, R. AND H. Kutter.

1951. Sur l'ethologie du nouveau myrmecobionte Epimyrma stumperi (nov. spec. Kutter). C. R. Acad. Sci (Paris) 233: 983-985.

TALBOT, M.

1976. The natural history of the workerless ant parasite Formica talbotae. Psyche 83: 282-288.

1979. Social parasitism among ants at the E. S. George preserve in southern Michigan. Great Lakes Entomol. 12: 87-89.

TAYLOR, R. W.

1967. The Australian workerless inquiline ant Strumigenys xenos Brown (Hymenoptera-Formicidae) recorded from New Zealand. New Zealand Entomol. 4: 47-49.

VANDEL, A.

1927. Observations sur les moeurs d'une fourmi parasite: Epimyrma vandeli Santschi. Bull. soc. entomo. Fr. 1927: 289-295. 
WHEELER, W. M.

1910. Ants: their structure, development and behavior. Columbia University Press, New York.

1919. The parasitic aculeata, a study in evolution. Proc. Am. Philos. Soc. 58: $1-40$.

1933. A second parasitic Crematogaster. Psyche 40: 83-86.

Whitford, W. G., P. Johnson and J. Ramirez.

1976. Comparative ecology of the harvester ants Pogonomyrmex barbatus (F. Smith) and Pogonomyrmex rugosus (Emery). Insectes Soc. 23: 117-132. WiLSON, E. O.

1963. Social modifications related to rareness in ant species. Evolution 17: 249253.

1971. The insect societies. Belknap Press of Harvard University Press, Cambridge, Massachusetts.

1976. The first workerless parasite in the ant genus Formica (Hymenoptera: Formicidae). Psyche 83: 277-281. 

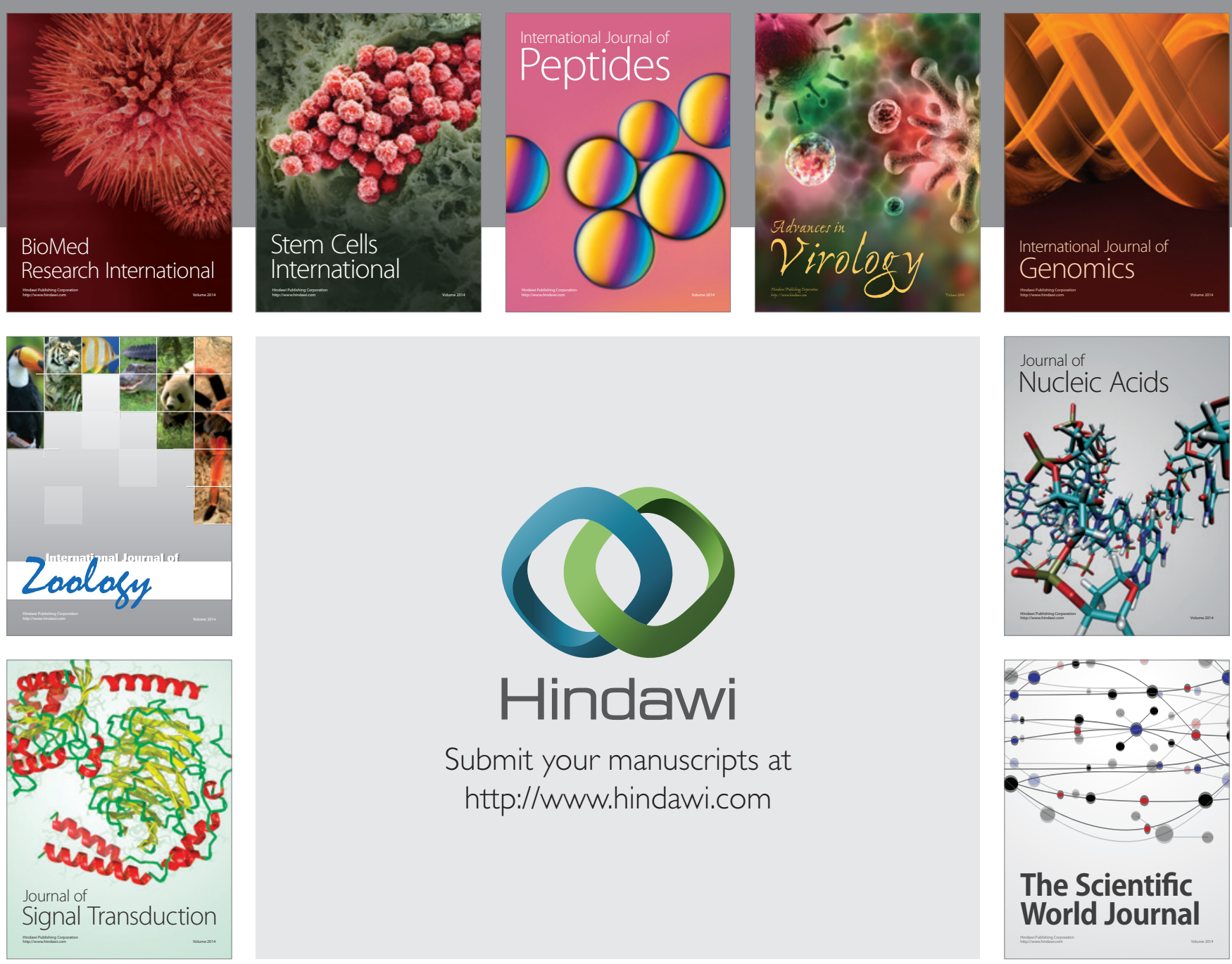

Submit your manuscripts at

http://www.hindawi.com
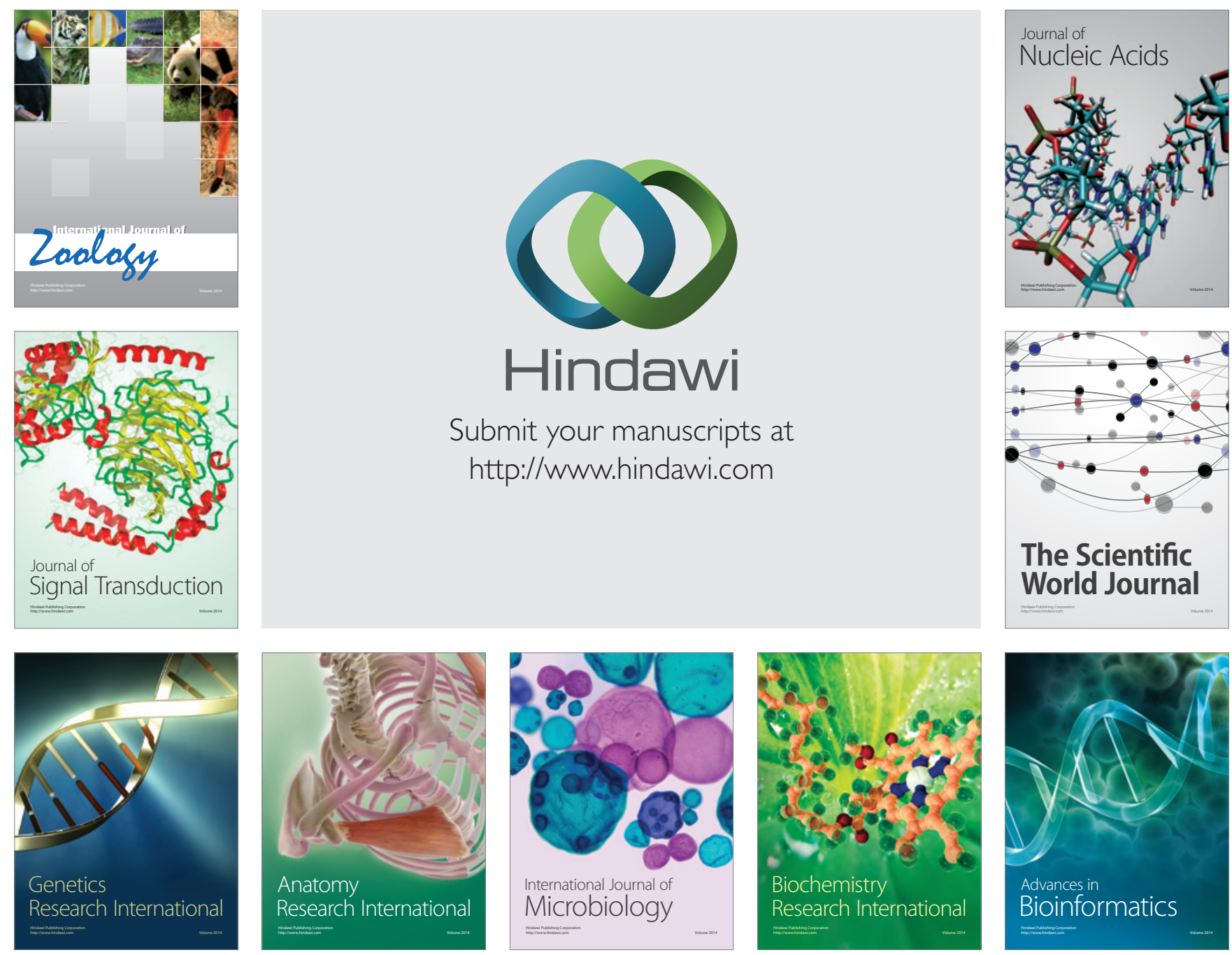

The Scientific World Journal
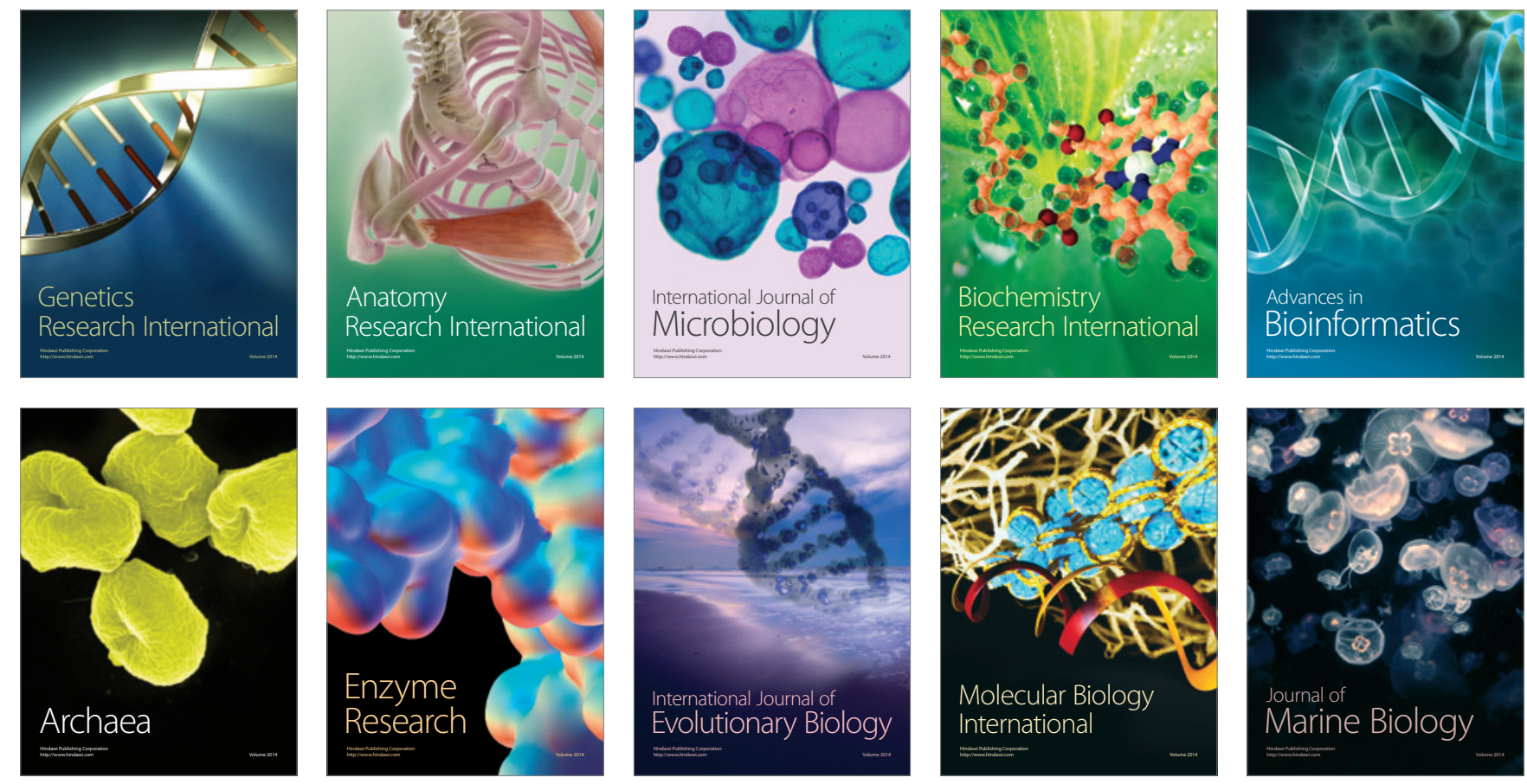